\title{
GRASSES AND LEGUMES AS COVER CROPS AFFECT MICROBIAL ATTRIBUTES IN OXISOL IN THE CERRADO (SAVANNAH ENVIRONMENT) IN THE NORTHEAST REGION ${ }^{1}$
}

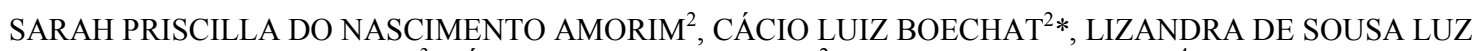 \\ DUARTE $^{3}$, CÍNTIA BEZERRA ROCHA ${ }^{2}$, FILIPE SELAU CARLOS ${ }^{4}$
}

\begin{abstract}
The cover crop straw may cause changes in the microbial activity and population, with repercussions on environmental changes and on the $\mathrm{C}$ and $\mathrm{N}$ dynamics, providing important information for the planning of adequate land use in the Cerrado. The objective of this study was to evaluate the effect of straw of cover crops on the soil microbial attributes and quality of organic matter. Experimental units consisted of $100 \mathrm{~g}$ of sieved soil placed in small plastic cups mixed with straw from cover plants. Treatments were distributed in a CRD, in a factorial scheme of $7 \times 7+1$, with seven types of straw, evaluated at 7, 14, 21, 28, 42, 63 and 105 days after incubation, and control without straw, with three replicates. The $\mathrm{qCO}_{2}$ ranged from 0.1 (Crotalaria spectabilis at 14 days) to $5.1 \%$ (Cajanus cajan 'IAPAR 43' at 42 days). The organic carbon and nitrogen reservoir are differently affected by straw of legumes and grasses on the dates. The incorporation of Brachiaria brizantha and Mucuna aterrima had a positive impact on the microbial attributes until the $21^{\text {st }}$ incubation $\left(\mathrm{qCO}_{2}, \mathrm{C}_{\text {mic }}\right.$ and $\mathrm{N}_{\text {mic }}$ ), with little loss of carbon dioxide and growth of the microbial population. All the evaluated species presented a potential to be used in crop rotation systems, enabling no-tillage systems in the Cerrado of Piauí. However, it is recommended to select species according to specific purposes. Thus, the use of cover crops is an important tool for increasing the biological quality of Brazilian northeastern cerrado soils.
\end{abstract}

Keywords: Grasses. legumes. Microbial biomass. Metabolic quotient. Soil quality.

\section{GRAMÍNEAS E LEGUMINOSAS COMO COBERTURA AFETAM ATRIBUTOS MICROBIANOS EM LATOSSOLO DO CERRADO NA REGIÃO NORDESTE}

RESUMO - A presença de palhada de plantas de cobertura pode causar mudanças significativas na atividade e população microbiana com efeitos ambientais e na dinâmica de $\mathrm{C}$ e $\mathrm{N}$ no solo, fornecendo informações importantes para o planejamento do uso adequado da terra no Cerrado brasileiro. O objetivo deste trabalho foi avaliar o efeito da palhada de plantas de cobertura sobre os atributos microbianos do solo, e na qualidade da matéria orgânica. As unidades experimentais consistiram de potes plásticos acondicionados com $100 \mathrm{~g}$ de solo misturados com palhada de plantas de cobertura. Os tratamentos foram distribuídos em um DIC, em esquema fatorial $7 \times 7+1$, com sete tipos de palhadas, avaliados aos 7, 14, 21, 28, 42, 63 e 105 dias após a incubação, e controle sem palhada, com três repetições. $\mathrm{O} \mathrm{qCO}_{2}$ variou de 0,1 (Crotalaria spectabilis aos 14 dias) a $5,1 \%$ (Cajanus cajan 'IAPAR 43' aos 42 dias). Os reservatórios de carbono e nitrogênio orgânicos são afetados de diferentes formas pelas palhadas de leguminosas e gramíneas em cada data de avaliação. A incorporação de Brachiaria brizantha e Mucuna aterrima tiveram impactos positivos nos atributos microbianos até o $21^{\circ}$ dia de incubação ( $\mathrm{qCO}_{2}, \mathrm{C}_{\text {mic }}$ and $\mathrm{N}_{\text {mic }}$ ), com baixa liberação de $\mathrm{CO}_{2}$ e aumento da população microbiana. Todas as espécies avaliadas apresentaram potencial para serem usadas em sistema de rotação, tornando viável para o plantio direto na região do Cerrado piauiense. Contudo, é recomendado a seleção de espécies de acordo com o propósito específico.

Palavras-chave: Gramíneas. leguminosas. Biomassa microbiana. Quociente metabólico. Qualidade do solo.

\footnotetext{
${ }^{*}$ Corresponding author

${ }^{1}$ Received for publication in $08 / 28 / 2018$; accepted in $05 / 11 / 2019$.

Paper extracted from the master dissertation of the first author.

${ }^{2}$ Universidade Federal do Piauí, Bom Jesus, PI, Brazil; amorimspn1@gmail.com - ORCID: 0000-0002-2360-8401, cacioboechat@gmail.com - ORCID: 0000-0002-5086-9156, cinthiarocha95@gmail.com - ORCID: 0000-0002-5873-3536.

${ }^{3}$ Universidade Federal do Rio Grande do Sul, Porto Alegre, RS, Brazil; lizandrasousaluzduarte12@gmail.com - ORCID: 0000-0002-93605791.

${ }^{4}$ Universidade Federal de Pelotas, Capão do Leão, RS, Brazil; filipeselaucarlos@hotmail.com - ORCID: 0000-0002-3068-0399.
} 


\section{INTRODUCTION}

The southwest region of Piaui is part of the Brazilian agricultural frontier called MATOPIBA (Maranhão, Tocantins, Piauí and Bahia), which is currently undergoing a great agricultural expansion and intensification of land use for the cultivation of grains, fibers, energy materials, perennial crops and irrigated agriculture (FONTANA et al., 2016; SOUSA et al., 2019). Management systems aimed at soil conservation have been widely discussed and applied, such as crop rotation, the use of cover plants, non-till or minimal tilling, which are directed at mitigating the negative effects of conventional management practices in soils, due to the loss of nutrients, of organic matter, the reduction of microbial diversity, changes in the structure of the edaphic fauna, increased gas emission, besides chemical and physical degradation (GUO et al., 2018; ZHANG et al., 2016).

Conservationist agricultural practices aiming to maintain dead soil cover provide the highest carbon levels in humic fractions, influence mineralization and nutrient immobilization, increase water infiltration into soil, reduce surface runoff and erosion, and serve as a primary form of organic matter input that enhances soil biological activity, conserves moisture and moderates soil temperature (NOVAK et al., 2017; OLIVEIRA et al., 2016; SOUZA; FIGUEIREDO; SOUSA, 2016). Hence, soil management practices alter the biological communities in soil, in the dynamics of the transient and humified organic matter reservoirs and in cycling soil nitrogen and carbon (GUO et al., 2018).

The biological community of the soil is therefore considered a nutrient source/drain, and it is responsible for nutrient cycling and reserves, besides the turnover of carbon in the soil-plant-atmosphere system (HU et al., 2016; ZHANG et al., 2015b). The microbial attributes of the soil, such as carbon $\left(\mathrm{C}_{\text {mic }}\right)$ and nitrogen $\left(\mathrm{N}_{\text {mic }}\right)$ of the microbial biomass and baseline respiration are considered sensitive indicators of the changes caused by soil use and have been widely utilized in studies of the alterations or changes in the quality of soils in areas with a minimal anthropic intervention or cultivation (GUO et al., 2018; MANDAKOVIC et al., 2018; RODRÍGUEZ et al., 2018). These indicators can identify short term changes allowing strategies to be planned to mitigate problems caused in minimally disturbed or anthropized environments (BOECHAT et al., 2012; SANTOS et al., 2016). However, these studies have not been performed for the soil conditions of the Cerrado in southwest Piauí, with poor results for non -till or minimal tilling, especially regarding the microbial effects of the addition of straw, which is an essential factor for the good performance of the nutrient cycling and biological system (ZHANG et al., 2016; NOVAK et al., 2017). Studies about changes in microbial attributes correlated with techniques for introducing cover crops capable of promoting high microbial activity and maintaining the soil cover ratio may favor the expansion of conservation systems. In this sense, the Cerrado of the Brazilian Northeast is currently a region of widely planted with grain crops, mainly soybeans. In this sense, it is essential to assess the magnitude of the impacts of major practices such as cover crops in these new agricultural production scenarios.

In the Cerrado of Piauí, studies with cover crop species are necessary to estimate the microbial activity associated with biomass and the cycling nutrients of plant residues and to define the appropriate species to enable non -till in the region. Therefore, the objective of this study is to evaluate the effect of straw of cover crop species on the microbial flow of carbon dioxide, carbon and nitrogen stocks on microbial biomass, quality of organic matter and microbial activity in the soil of Cerrado of Piauí.

\section{MATERIAL AND METHODS}

\section{Sampling soil and cover plants}

Soil samples used in the experiment were collected at the site where cover plants were cultivated at the depth of $0-20 \mathrm{~cm}$ at geographical coordinates $08^{\circ} 71^{\prime} 01^{\prime \prime} \mathrm{S}$ and $45^{\circ} 01^{\prime} 14^{\prime}$ ' $\mathrm{W}$ in the savanna biome (Cerrado) of the Northeast Region, Piauí State, Brazil. The soil was classified according to the Brazilian Soil Classification System as Latossolo Amarelo eutrófico (SANTOS et al., 2013) or according to the United States Department of Agriculture as Oxisol Ustox (SOIL SURVEY STAFF, 2014). Sub-samples were air dried, sieved in a $2 \mathrm{~mm}$ mesh sieve and homogenized for chemical and physical characterization (TEDESCO et al., 1995).

The soil sample presented the following chemical and physical characterization: $\mathrm{pH}$ in water 5.9; $\mathrm{H}+\mathrm{Al}, \mathrm{Al}^{3+}$ and $\mathrm{Ca}^{2+}+\mathrm{Mg}^{2+} 4.0 ; 1.0$ and 5.4 $\mathrm{cmol}_{\mathrm{c}} \mathrm{dm}^{-3}$, respectively; $\mathrm{P}$ and $\mathrm{K} 60.1$ and $90.0 \mathrm{mg}$ $\mathrm{dm}^{-3}$, respectively; organic matter $15.9 \mathrm{~g} \mathrm{~kg}^{-1}$; $\mathrm{NH}_{4}{ }^{+}+\mathrm{NO}_{3}{ }^{-}$of $53.0 \mathrm{mg} \mathrm{kg}^{-1}$ sum of bases and cationexchange capacity 5.7 and $9.7 \quad \mathrm{cmol}_{\mathrm{c}} \mathrm{dm}^{-3}$, respectively; saturation of bases and aluminum of 59.0 and $1.7 \%$, respectively and clay, silt and sandy contents $243.0 ; 12.0$ and $744.0 \mathrm{~g} \mathrm{~kg}^{-1}$, respectively.

At the time of sowing $173.4 ; 22.5 ; 0.45$ and $50 \mathrm{~kg} \mathrm{ha}^{-1}$ of boron (Borogran), sulfur (Sulfogran $\left.90^{\circledR}\right), \mathrm{K}_{2} \mathrm{O}(\mathrm{KCl})$ and $\mathrm{P}_{2} \mathrm{O}_{5}$ (superphosphate simple), respectively, were applied to the soil. The cover species was sown in a haul with a leveling grid passage in $12 \mathrm{~m} \mathrm{x} 12.5 \mathrm{~m}$ plots in the beginning of January 2015. The following quantity of seeds was sown per hectare: $3.5 \mathrm{~kg}$ Brachiaria brizantha; 15.0 $\mathrm{kg}$ of Crotalaria spectabilis; $45.0 \mathrm{~kg}$ of Cajanus 
cajan 'IAPAR 43'; $35.0 \mathrm{~kg}$ of Pennisetum glaucum 'BRS 1501'; $60.0 \mathrm{~kg}$ of Mucuna aterrima; $60.0 \mathrm{~kg}$ of Cajanus cajan 'IAC Broad pod' and $10 \mathrm{~kg}$ of Crotalaria ochroleuca.

The plants were desiccated at maturity at 183 days after sowing using two commercial formulations, potassium glyphosate base, at a dose of $2.0 \mathrm{~L} \mathrm{ha}^{-1}$. Then, flumioxazin-based herbicide was applied at a dose of $0.1 \mathrm{~L} \mathrm{ha}^{-1}$. After the plants died and the field had dried, samples of the cover plants were collected with the aid of a cutlass, cutting close to the soil surface. The samples were packed in identified paper bags, placed in an oven to dry with forced air circulation at $65{ }^{\circ} \mathrm{C}$ for 48 hours and then fragmented into 1 to $3 \mathrm{~cm}$ fractions.

Samples with $1 \mathrm{~g}$ (dry weight) of each species were digested with nitro-perchloric acid solution (TEDESCO et al., 1995). The extracts were analyzed by atomic absorption spectrometry with induced plasma and the results of macro and micronutrient contents and the $\mathrm{C}: \mathrm{N}$ ratio are shown in Table 1.

Table 1. Macro and micronutrient contents in the straw of single cover plant species

\begin{tabular}{|c|c|c|c|c|c|c|c|c|c|c|}
\hline CPS & $\mathrm{Fe}$ & $\begin{array}{c}\mathrm{Mn} \\
-\mathrm{mg} \mathrm{k}\end{array}$ & $\mathrm{Zn}$ & $\mathrm{Mg}$ & $\mathrm{Ca}$ & $\begin{array}{c}\mathrm{P} \\
\mathrm{g} \mathrm{kg}^{-1}\end{array}$ & $\begin{array}{r}\mathrm{K} \\
\\
\end{array}$ & $\begin{array}{l}\mathrm{N} \\
-\%\end{array}$ & $\begin{array}{c}\mathrm{C} \\
- \\
-\end{array}$ & $\mathrm{C}: \mathrm{N}$ ratio \\
\hline PG & 237.0 & 43.2 & 45.2 & 3.5 & 22.1 & 3.7 & 11.2 & 1.58 & 51.5 & 32.6 \\
\hline BB & 289.0 & 50.8 & 50.6 & 4.4 & 22.6 & 2.7 & 13.9 & 1.63 & 50.7 & 31.2 \\
\hline MA & 228.3 & 54.9 & 48.0 & 3.2 & 15.9 & 3.9 & 11.4 & 2.67 & 51.6 & 19.4 \\
\hline $\mathrm{CO}$ & 194.4 & 45.8 & 38.2 & 4.5 & 3.0 & 4.0 & 15.3 & 1.94 & 53.4 & 27.5 \\
\hline $\mathrm{CS}$ & 277.0 & 50.8 & 45.0 & 4.5 & 27.0 & 4.0 & 13.9 & 1.85 & 53.5 & 28.9 \\
\hline $\mathrm{CCB}$ & 239.5 & 45.4 & 43.3 & 3.6 & 24.2 & 3.8 & 10.6 & 2.20 & 53.4 & 24.3 \\
\hline CCI & 225.0 & 43.8 & 50.5 & 3.4 & 28.0 & 3.9 & 10.0 & 2.40 & 51.9 & 21.7 \\
\hline
\end{tabular}

CPS - cover plant straw; PG - Pennisetum glaucum 'BRS 1501'; BB - Brachiaria brizantha; MA - Mucuna aterrima; CO - Crotalaria ochroleuca; CS - Crotalaria spectabilis; CCB - Cajanus cajan 'IAC Broad pod'; CCI - Cajanus cajan 'IAPAR $43^{\prime}$.

\section{Incubation experiment}

Approximately $100 \mathrm{~kg}$ of soil sample collected was sieved $(\varnothing<4.75 \mathrm{~mm})$, homogenized, moistened (close to $70 \%$ of water retention capacity) and stored in plastic bags in a dark environment at a room temperature of $28 \pm 4{ }^{\circ} \mathrm{C}$ for 21 days to restore microbial communities.

A 105-day incubation experiment was conducted aiming to evaluate soil microbial changes after incorporation of cover plant straw. Experimental units consisted of $100 \mathrm{~g}$ dry weight of sieved soil samples placed in small plastic cups (150 $\mathrm{mL})$. Straw from cover plants, equivalent to $10 \mathrm{Mg}$ $\mathrm{ha}^{-1}$ providing an amount of 16 to $24 \mathrm{~kg} \mathrm{~N}^{-1}$ and 51 to $54 \mathrm{~kg} \mathrm{C} \mathrm{ha}^{-1}$ (Table 1), were mixed and added to soils vigorously for $2 \mathrm{~min}$. to ensure uniformity within and between samples, and deionized water was added to moisten soils to $70 \%$ of field capacity. The plastic bottles with treatments were then placed in a BOD incubator in the absence of light, at controlled temperature $\left(28 \pm 2.0^{\circ} \mathrm{C}\right)$ and humidity maintained close to $70 \%$ of field capacity. The moisture was checked by weighing every 7 days and adjusted with distilled water.

Treatments were distributed in a completely randomized experimental design in a factorial scheme $7 \times 7+1$, with seven types of straw from cover plants (PG, BB, MA, CO, CS, CCB and CCI) incorporated into the soil, evaluated at $7 ; 14 ; 21 ; 28$; 42; 63 and 105 days after incubation, plus a soil without incorporation of straw (control) with three replicates.

\section{Microbial evaluations}

Soil basal respiration (SBR) was determined according to Jenkinson and Powlson (1976) by incubating experimental units placed on the surface of respirometric glass pots with a tightly sealed screw cap. A second cup containing $30 \mathrm{ml}$ of $1 \mathrm{Mol}$ $\mathrm{L}^{-1} \mathrm{NaOH}$ solution was added for the capture of $\mathrm{CO}_{2}$ and another containing $30 \mathrm{ml}$ of distilled water in order to keep the internal moisture constant. Four blank controls (without soil and straw), were added to eliminate the effect of atmospheric carbon dioxide $\left(\mathrm{CO}_{2}\right)$ contamination on the system in the assessment of soil basal respiration.

At $7 ; 14 ; 21 ; 28 ; 42 ; 63$ and 105 days after incubation, $\mathrm{CO}_{2}$ was withdrawn from the bottle with a solution of $\mathrm{NaOH}$ and added to $10 \mathrm{~mL}$ of $0.5 \mathrm{~mol} \mathrm{~L}$ ${ }^{-1} \mathrm{BaCl}_{2}$ and 3 drops of phenolphthalein indicator at $1 \%$. The amount of $\mathrm{CO}_{2}$ released from the soil was determined by titration of excess $\mathrm{NaOH}$ with 0.025 
Mol L-1 $\mathrm{HCl}$ solution. At each evaluation, the $1 \mathrm{Mol}$ $\mathrm{L}^{-1} \mathrm{NaOH}$ solution was replenished and the glass vessel resealed.

The soil basal respiration was measured by the sum of $\mathrm{CO}_{2}$ released during the entire incubation period divided by the duration in hours. The $\mathrm{C}-\mathrm{CO}_{2}$ released per hour of incubation period was calculated by Equation 1 and expressed in $\mathrm{mg} \mathrm{C}-\mathrm{CO}_{2}$ $100 \mathrm{~g}^{-1}$ soil h$^{-1}$ :

\section{(Equation 1)}

$\mathrm{SBR}=(((\mathrm{Vb}-\mathrm{Va}) \times \mathrm{M} \times 6 \times 1000) / \mathrm{Ps}) / \mathrm{T}$

where, $\mathrm{SBR}=$ carbon derived from soil basal respiration $\left(\mathrm{mg} \mathrm{C}-\mathrm{CO}_{2} \mathrm{~g}^{-1} \mathrm{~h}^{-1}\right), \mathrm{Vb}(\mathrm{mL})=$ volume of hydrochloric acid used for titration of the control solution (blank), $\mathrm{Va}(\mathrm{mL})=$ volume required in the sample; $\mathrm{M}=\mathrm{HCl}$ molarity; $6=$ equivalent weight of $\mathrm{C}-\mathrm{CO}_{2}$. According to the Richter Law, the equivalent weight of an element or substance is the mass of the substance corresponding to $8 \mathrm{~g}$ of oxygen (the standard most commonly used). In the case of $\mathrm{CO}_{2}$, it was found that the proportion of elements $\mathrm{C}$ and $\mathrm{O}$ is 3:8 g; Ps $(\mathrm{g})=$ dry soil mass; and $\mathrm{T}(\mathrm{h})=$ time.

The microbial biomass carbon $\left(\mathrm{C}_{\text {mic }}\right)$ and nitrogen $\left(\mathrm{N}_{\text {mic }}\right)$ were determined using, instead of chloroform, the microwave irradiation technique proposed by Ferreira; Camargo; Vidor (1999) in order to kill the microorganisms and trigger the release of cellular components.

A solution of $\mathrm{K}_{2} \mathrm{SO}_{4} \quad 0.5 \quad \mathrm{Mol} \quad \mathrm{L}^{-1}$ (soil:extractant $=1: 4$ ) was added to the radiated and non- radiated soils followed by horizontal circular shaking at $220 \mathrm{rpm}$ for $30 \mathrm{~min}$. The extracts were left to rest for another 30 minutes and filtered through Whatman ${ }^{\circledR} \mathrm{n}^{\circ} 42$ filter paper (diameter 7 $\mathrm{cm})$. The $\mathrm{C}_{\text {mic }}$ and $\mathrm{N}_{\text {mic }}$ contents in extracts were determined by the wet combustion method and Kjeldahl-N (TEDESCO et al., 1995).

The microbial biomass carbon $\left(\mathrm{C}_{\text {mic }}\right)$ was calculated by following Equation 2 and expressed in mg $100 \mathrm{~g}^{-1}$ soil:

$$
\mathrm{C}_{\text {mic }}=\mathrm{EC} / \mathrm{KC}
$$

(Equation 2)

where, $\mathrm{EC}=$ (organic $\mathrm{C}$ extracted from radiated soil) - (organic $\mathrm{C}$ extracted from nonradiated soil) and $\mathrm{KC}=$ conversion factor of 0.33 (ISLAM; WEIL, 1998), for fumigation extraction or radiation extraction method, i.e., a weighting factor
(C mineralization - a proportion of microbial $\mathrm{C}$ released as $\mathrm{CO}_{2}$ during incubation).

The microbial biomass nitrogen $\left(\mathrm{N}_{\text {mic }}\right)$ was calculated by following Equation 3 and expressed in mg $100 \mathrm{~g}^{-1}$ soil:

$$
\mathrm{N}_{\text {mic }}=\mathrm{EN} / \mathrm{KEN}
$$

(Equation 3)

where, $\mathrm{EN}=($ total $\mathrm{N}$ extracted from radiated soil) - (total $\mathrm{N}$ extracted from non-radiated soil) and $\mathrm{KEN}=$ is a constant representing the $\mathrm{N}$ rate of mineralized microbial biomass. The KEN value used in this study was the factor 0.54 , as suggested by Brookes et al. (1985).

The metabolic quotient $\left(\mathrm{qCO}_{2}\right)$ was calculated as the ratio between soil basal respiration rate and microbial biomass $\mathrm{C}$ and expressed as $\mathrm{mg} \mathrm{CO}_{2} \mathrm{~g}^{-1}$ $\mathrm{C}_{\text {mic }} \mathrm{h}^{-1}$ (ANDERSON; DOMSH, 1993). The microbial quotient (qMIC) was calculated as the ratio between soil microbial biomass $\mathrm{C}$ and total soil carbon (WALKLEY; BLACK, 1934) expressed as $\%$.

\section{Statistical analysis}

Data were submitted to analysis of variance using the F-test at 5\%. The Scott-Knott's test at a significance level of $\mathrm{p}<0.05$ was used to compare mean values for each variable studied using Sisvar (FERREIRA, 2011).

\section{RESULTS AND DISCUSSION}

In the deployment of the use of cover crops within each assessment date, soil basal respiration (SBR) was observed at 7, 14 and 105 days after incubation with a lower values in the control treatment (soil without cover plant straw) and higher values were found in the other treatments with values ranging from 66.45 ( $\mathrm{CO}$ - Crotalaria ochroleuca) to $86.29 \mathrm{mg} \quad \mathrm{CO}_{2} \quad 100 \mathrm{~g}^{-1} \mathrm{~h}^{-1}(\mathrm{CS}$ - Crotalaria spectabilis) at 7 days; from 107.71 (BB - Brachiaria brizantha) to $133.17 \mathrm{mg} \mathrm{CO} 2100 \mathrm{~g}^{-1} \mathrm{~h}^{-1}$ (CCI Cajanus cajan 'IAPAR 43') at 14 days and, from 46.04 (MA - Mucuna aterrimaand CCI) to $75.18 \mathrm{mg}$ $\mathrm{CO}_{2} 100 \mathrm{~g}^{-1} \mathrm{~h}^{-1}$ (PG - Pennisetum glaucum) at 105 days. However, no significant differences were observed between these treatments (Table 2). 
Table 2. Soil basal respiration ( $\mathrm{mg} \mathrm{C}-\mathrm{CO}_{2} 100 \mathrm{~g}^{-1} \mathrm{~h}^{-1}$ ) comparing cover crop use on each assessment date up to 105 days on an Oxisol.

\begin{tabular}{llllllll}
\hline \multirow{2}{*}{ Treatment } & \multicolumn{6}{l}{ Period in days } \\
\cline { 2 - 7 } & 7 & 14 & 21 & 28 & 42 & 63 & 105 \\
\hline PG & $72.82 \mathrm{a}$ & $108.69 \mathrm{a}$ & $84.57 \mathrm{~b}$ & $68.9 \mathrm{a}$ & $48.26 \mathrm{~b}$ & $105.78 \mathrm{a}$ & $75.18 \mathrm{a}$ \\
$\mathrm{BB}$ & $76.75 \mathrm{a}$ & $107.71 \mathrm{a}$ & $108.28 \mathrm{a}$ & $95.83 \mathrm{a}$ & $69.92 \mathrm{a}$ & $87.86 \mathrm{~b}$ & $67.16 \mathrm{a}$ \\
$\mathrm{MA}$ & $81.05 \mathrm{a}$ & $111.95 \mathrm{a}$ & $83.78 \mathrm{~b}$ & $57.81 \mathrm{~b}$ & $47.88 \mathrm{~b}$ & $72.99 \mathrm{~b}$ & $46.04 \mathrm{a}$ \\
$\mathrm{CS}$ & $86.29 \mathrm{a}$ & $128.6 \mathrm{a}$ & $101.17 \mathrm{a}$ & $78.4 \mathrm{a}$ & $66.88 \mathrm{a}$ & $94.85 \mathrm{a}$ & $56.6 \mathrm{a}$ \\
$\mathrm{CO}$ & $66.45 \mathrm{a}$ & $116.85 \mathrm{a}$ & $101.17 \mathrm{a}$ & $76.82 \mathrm{a}$ & $71.06 \mathrm{a}$ & $103.16 \mathrm{a}$ & $61.88 \mathrm{a}$ \\
$\mathrm{CCB}$ & $73.38 \mathrm{a}$ & $118.48 \mathrm{a}$ & $86.94 \mathrm{~b}$ & $81.18 \mathrm{a}$ & $70.68 \mathrm{a}$ & $99.22 \mathrm{a}$ & $55.75 \mathrm{a}$ \\
$\mathrm{CCI}$ & $79.37 \mathrm{a}$ & $133.17 \mathrm{a}$ & $103.14 \mathrm{a}$ & $78.01 \mathrm{a}$ & $63.84 \mathrm{a}$ & $78.68 \mathrm{~b}$ & $46.04 \mathrm{a}$ \\
Control & $37.63 \mathrm{~b}$ & $32.00 \mathrm{~b}$ & $34.38 \mathrm{c}$ & $36.04 \mathrm{c}$ & $40.66 \mathrm{~b}$ & $17.92 \mathrm{c}$ & $19.96 \mathrm{~b}$ \\
\hline C.V. & 17.23 & & & & & & \\
\hline
\end{tabular}

PG - Pennisetum glaucum 'BRS 1501'; BB - Brachiaria brizantha; MA Mucuna aterrima; CO - Crotalaria ochroleuca; CS - Crotalaria spectabilis; CCB - Cajanus cajan 'IAC Broad pod'; CCI - Cajanus cajan 'IAPAR 43'; control - soil without straw; nd - no significant difference; C.V. - coefficient of variation. Means followed by the same letter in the column comparing treatments at each date do not differ by Scott-Knott test $(\mathrm{p}<0.05)$.

Organic material mixed with soil by cover plant straw increases soil microbial activity, both with legumes and grass straw (Table 2). At 21 days of incubation the SBR were higher in the BB, CS, $\mathrm{CO}$ and $\mathrm{CCI}$ treatments, followed by $\mathrm{PG}, \mathrm{MA}$ and GS and lower SBR were observed in the control treatment. The best results for SBR were approximately 3.2 times higher than in the control (Table 2). At 28 days no significant differences were found between studied treatments, except in the MA, followed by the control with worse results for this variable. The same results were found for MA and PG at 42 days, followed by the control. At 63 days of incubation the higher values were observed in the $\mathrm{PG}, \mathrm{CS}, \mathrm{CO}$ and Cajanus cajan 'IAC Broad pod'(CCB) treatments and the lowest value in the control (Table 2).

At 7, 14, 21, 28, 42, 63 and 105 days, soil basal respiration was approximately $2.3 ; 4.2 ; 3.2$; $2.7 ; 1.7 ; 5.9$ and 3.8 times lower in the soil without input of cover plant straw (control) than the highest value found in the treatments (Table 2). This can be explained because in the tropical climate soil microbial stimulation was highly sensitive to the quality and quantity of the organic residues incorporated to the soil (BOECHAT et al., 2012; NOVAK et al., 2017; OLIVEIRA et al., 2016). Moreover, the data show that high values for base respiration do not always indicate conditions of stress, as a high rate of respiration can, in the short term, mean efficient nutrient cycling, and in the long term, increase the soil microbial population in number and diversity improving the environmental services and the biological quality of this soil.

In the deployment of the assessment date within each cover crop treatments observed showed an increase in $\mathrm{CO}_{2}$ release until 14 days of incubation, except for the control treatment. After 14 days, a decrease in $\mathrm{CO}_{2}$ concentrations until 42 days and a stabilization of $\mathrm{CO}_{2}$ release in the control treatment was observed, and a small decrease among treatments with straw incorporated after this time period (Figure 1). 


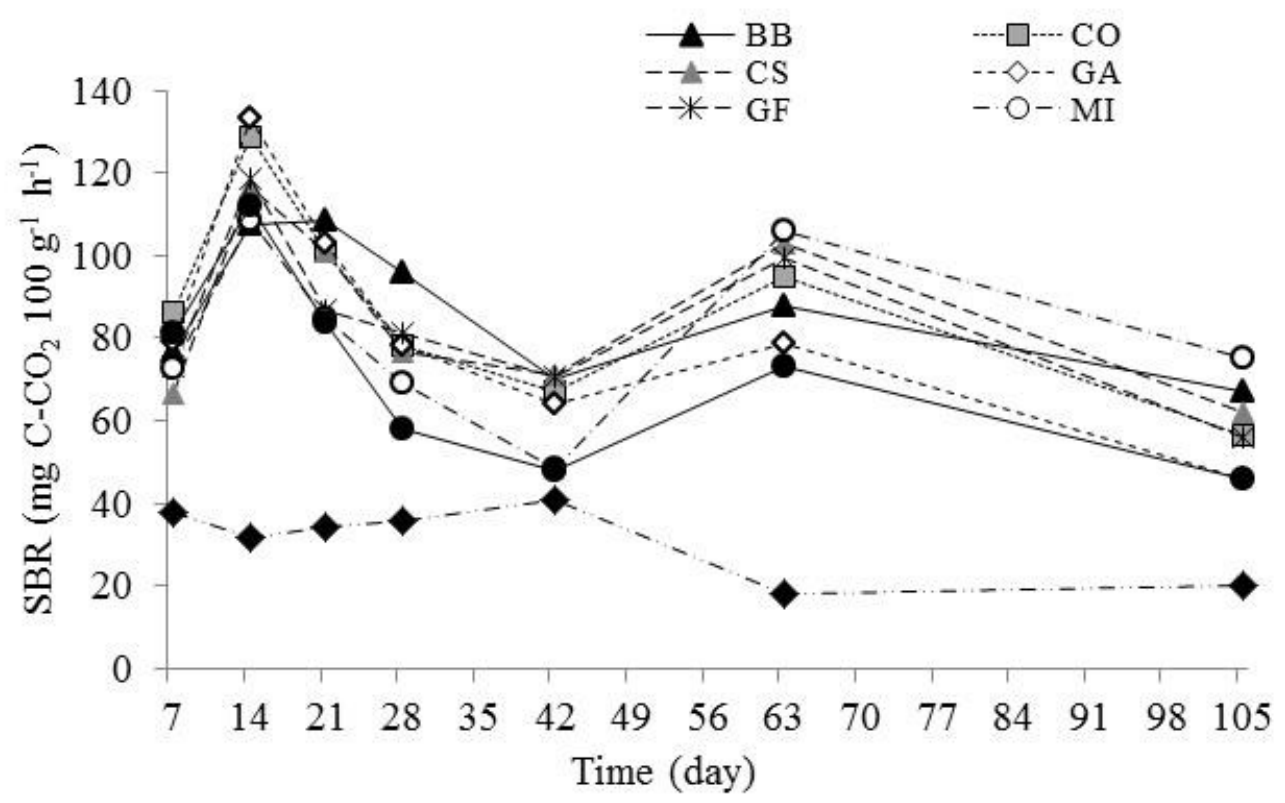

Figure 1. Soil basal respiration (SBR) evaluated up to 105 days of incubation for each cover plant studied in an Oxisol.

A high increase among treatments with straw incorporated was observed at 14 days (Figure 1). Probably, with the decrease of transitory organic matter (non-humic substances) formed by more labile organic compounds, a decrease in population and microbial activity occurs (from 14 to 42 days) and new biomass is formed by the degradation of the microorganisms and organic compounds released in the previous phase (at 63 days) and in the final phase with the degradation of more recalcitrant compounds like lignin (after 63 days), the microbial activity again tends to stabilize (BURNS et al., 2013). The differences between the treatments on each date may be explained by the chemical composition of the plant cover straws studied (Tables 1 and 2 and Figure 1).

In the deployment of the use of cover crops within each assessment date at 7 days of incubation, $\mathrm{C}_{\text {mic }}$ did not differ between treatments. The highest $\mathrm{C}_{\text {mic }}$ at 14 days $\left(407.35 \mathrm{mg} 100 \mathrm{~g}^{-1}\right.$ ) was observed in the treatment with Brachiaria brizantha $(\mathrm{BB})$ straw incorporation, followed by $\mathrm{MA}, \mathrm{CO}, \mathrm{CCB}$ and $\mathrm{CCI}$ (Table 3).

Table 3. Microbial biomass carbon (mg $\left.100 \mathrm{~g}^{-1}\right)$ for 105 days of incubation after incorporation of grasses and legume straw in an Oxisol.

\begin{tabular}{llllllll}
\hline \multirow{2}{*}{ Treatment } & \multicolumn{7}{l}{ Period in days } \\
\cline { 2 - 8 } & 7 & 14 & 21 & 28 & 42 & 63 & 105 \\
\hline PG & $50.90^{\text {nd }}$ & $141.81 \mathrm{c}$ & $32.72 \mathrm{~b}$ & $21.81 \mathrm{~b}$ & $276.36 \mathrm{~b}$ & $133.57 \mathrm{a}$ & $319.99 \mathrm{a}$ \\
$\mathrm{BB}$ & 76.36 & $407.35 \mathrm{a}$ & $167.27 \mathrm{a}$ & $210.90 \mathrm{a}$ & $316.36 \mathrm{~b}$ & $135.55 \mathrm{a}$ & $250.90 \mathrm{~b}$ \\
MA & 87.27 & $276.36 \mathrm{~b}$ & $105.45 \mathrm{a}$ & $109.09 \mathrm{a}$ & $378.18 \mathrm{a}$ & $129.62 \mathrm{a}$ & $316.36 \mathrm{a}$ \\
$\mathrm{CS}$ & 50.90 & $10.91 \mathrm{~d}$ & $160.00 \mathrm{a}$ & $160.00 \mathrm{a}$ & $341.81 \mathrm{~b}$ & $145.43 \mathrm{a}$ & $283.63 \mathrm{~b}$ \\
$\mathrm{CO}$ & 47.27 & $254.54 \mathrm{~b}$ & $134.54 \mathrm{a}$ & $134.54 \mathrm{a}$ & $334.54 \mathrm{~b}$ & $148.20 \mathrm{a}$ & $385.45 \mathrm{a}$ \\
$\mathrm{CCB}$ & 123.63 & $243.63 \mathrm{~b}$ & $50.90 \mathrm{~b}$ & $58.18 \mathrm{~b}$ & $407.27 \mathrm{a}$ & $153.33 \mathrm{a}$ & $254.54 \mathrm{~b}$ \\
$\mathrm{CCI}$ & 130.90 & $218.18 \mathrm{~b}$ & $18.18 \mathrm{~b}$ & $32.72 \mathrm{~b}$ & $450.91 \mathrm{a}$ & $139.11 \mathrm{a}$ & $229.09 \mathrm{~b}$ \\
Control & 14.54 & $69.09 \mathrm{~d}$ & $36.36 \mathrm{~b}$ & $36.36 \mathrm{~b}$ & $72.73 \mathrm{c}$ & $40.00 \mathrm{~b}$ & $60.00 \mathrm{c}$ \\
\hline C.V. & 27.47 & & & & & & \\
\hline
\end{tabular}

PG - Pennisetum glaucum 'BRS 1501'; BB - Brachiaria brizantha; MA - Mucuna aterrima; CO - Crotalaria ochroleuca; CS - Crotalaria spectabilis; CCB - Cajanus cajan 'iac Broad pod'; CCI - Cajanus cajan 'IAPAR 43'; control - soil without straw; nd - no significant difference; C.V. - coefficient of variation. Means followed by the same letters in the column do not differ by Scott-Knott test ( $p<$ $0.05)$. 
The straw of Pennisetum glaucum (PG) and Brachiaria brizantha $(\mathrm{BB})$ have a $\mathrm{C} / \mathrm{N}$ ratio $>30.0$ (Table 1) and approximately $40 \%$ of the accumulated phytomass of Pennisetum glaucum is from the stem, which consists of lignified tissues with a higher $\mathrm{C} / \mathrm{N}$ ratio than the leaves (SOUSA et al., 2019). This means that the $\mathrm{N}$ immobilization process predominates over $\mathrm{N}$ mineralization (MOREIRA; SIQUEIRA, 2006). If this is the case, there was a growth of the activity of the microbial population due to carbon and nitrogen from residue and nitrogen availability in the ammoniacal and nitric forms in the soil. Similarly, there will be net mineralization of $\mathrm{N}$ when the $\mathrm{C} / \mathrm{N}$ ratio is less than 30.0 as in the other residues (BOECHAT et al., 2013). However, the release rate of the element will be different according to the type of straw (CARDOSO; ANDREOTE, 2016).

The lower values for $\mathrm{C}_{\text {mic }}$ were found in the $\mathrm{CS}$ and control treatment (10.91 and $69.09 \mathrm{mg} 100 \mathrm{~g}$ 1 , respectively) as shown in Table 3 . The result of the control treatment was expected to be a lower $\mathrm{C}_{\text {mic }}$ ) but the response of the CS treatment is probably due to material composition, because at the time of the straw harvest, a great amount of organic material formed only by plant stems was observed. This occurs because the dry leaves were carried by the winds that are abundant in the Cerrado region, meaning that the CS straw was basically formed by material with a high lignin content, which is a more recalcitrant carbon source, degraded by specialized microorganisms which causes slow degradation of the material i.e. the quality of the plant residues has a great influence on how the microbial metabolism functions (BURNS et al., 2013; ZHANG et al., 2015a; SZOBOSZLAY; WHITE-MONSANT; MOE, 2016).
At 21 and 28 days high medium values ranging between 105.45 to $210.90 \mathrm{mg} 100 \mathrm{~g}^{-1}$ in the treatments $\mathrm{BB}, \mathrm{MA}, \mathrm{CS}$ and $\mathrm{CO}$, were observed, while other treatments did not differ presenting lower values for $\mathrm{C}_{\text {mic }}$. The higher values for $\mathrm{C}_{\text {mic }}$ at 42 days were observed in the legume treatments (MA, CCB e CCI), followed by $\mathrm{PG}, \mathrm{BB}, \mathrm{CS}$ and $\mathrm{CO}$ and, the lowest result was found in the control treatment. At 63 days of incubation a lower $\mathrm{C}_{\text {mic }}$ was observed in the control and a high $\mathrm{C}_{\text {mic }}$ in the treatments incorporating straw, but they did not differ from each other. The higher values for $\mathrm{C}_{\text {mic }}$ at 105 days were $319.9 ; 316.4$ and $385.5 \mathrm{mg} 100 \mathrm{~g}^{-1}$ in the $\mathrm{PG}, \mathrm{MA}$ and $\mathrm{CO}$, respectively. A lower $\mathrm{C}_{\text {mic }}$ value $\left(60.0 \mathrm{mg} 100 \mathrm{~g}^{-1}\right)$ was found in the control treatment (Table 3 ).

These results showed that cover plant straw positively affects $\mathrm{C}_{\text {mic }}$ according to type and time after incorporation. Soil microbiota is stimulated by the supply of plant residues with different chemical compositions and different degrees of susceptibility to decay, which favor the survival and growth of different groups of organisms (FERREIRA; WENDLAND; DIDONET, 2011).

In the deployment of the assessment date within each cover crop treatment an increase in the $\mathrm{C}_{\text {mic }}$ was observed until 14 days of incubation for all treatments, except for $\mathrm{CO}$ treatment that increased $\mathrm{C}_{\text {mic }}$ after 14 days of incubation (Figure 2). These results are according to those found for $\mathrm{CO}_{2}$ release (Figure 1), the microbial activity being a function of the growth of the microbial mass (population). However, after the $14^{\text {th }}$ to the $28^{\text {th }}$ day no increase was observed for all treatments, but it was different with the $\mathrm{C}_{\text {mic }}$ content from treatments. After 28 days of incubation a new carbon biomass increase was observed and stabilization after 42 days for all treatments.

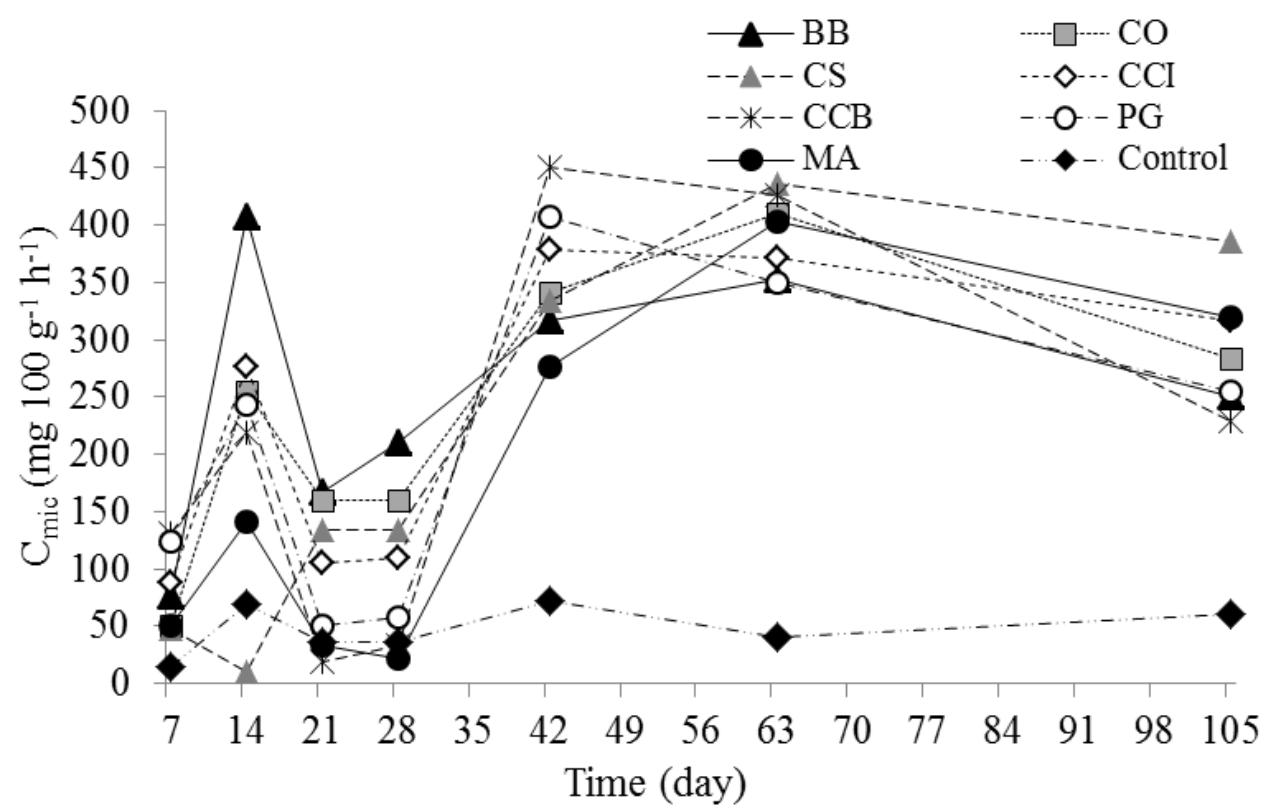

Figure 2. Microbial biomass carbon $\left(\mathrm{C}_{\mathrm{mic}}\right)$ evaluation for 105 days of incubation after incorporation of grasses and legume straw in an Oxisol.

Rev. Caatinga, Mossoró, v. 33, n. 1, p. 31 - 42, jan. - mar., 2020 
In the deployment of the use of cover crops within each assessment date, until 21 days no differences were observed between treatments for $\mathrm{N}_{\text {mic. }}$. At 28 days MA and CCB treatments have a higher $\mathrm{N}_{\text {mic }}$ value $\left(28.08 \mathrm{mg} 100 \mathrm{~g}^{-1}\right)$, followed by $\mathrm{CCI}$ and $\mathrm{CO}$ (21.17 mg $100 \mathrm{~g}^{-1}$ ). Treatments PG, MA, CS, CCB and CCI have high amounts of $\mathrm{N}_{\text {mic }}$ at
42 days of incubation, which was observed at 63 days for $\mathrm{BB}, \mathrm{MA}, \mathrm{CS}, \mathrm{CCB}$ and $\mathrm{CCI}$. The lower values were observed in the $\mathrm{CO}, \mathrm{BB}$ and Control at 42 days and control $\left(1.3 \mathrm{mg} 100 \mathrm{~g}^{-1}\right)$ at 63 days. However, at 105 days $\mathrm{CO}$ treatment has the highest amount of $\mathrm{N}_{\text {mic }}\left(37.59 \mathrm{mg} 100 \mathrm{~g}^{-1}\right)$, followed by the BB treatment (Table 4).

Table 4. Microbial biomass nitrogen (mg $\left.100 \mathrm{~g}^{-1}\right)$ for 105 days of incubation after incorporation of grasses and legume straw in an Oxisol.

\begin{tabular}{|c|c|c|c|c|c|c|c|}
\hline \multirow{2}{*}{ Treatment } & \multicolumn{7}{|c|}{ Period in days } \\
\hline & 7 & 14 & 21 & 28 & 42 & 63 & 105 \\
\hline PG & $1.29^{\text {nd }}$ & $3.02^{\text {nd }}$ & $7.34^{\text {nd }}$ & $5.61 \mathrm{~d}$ & $14.25 \mathrm{a}$ & $9.93 \mathrm{~b}$ & $17.71 \mathrm{c}$ \\
\hline BB & 3.02 & 6.48 & 6.48 & $12.53 \mathrm{c}$ & $9.07 \mathrm{~b}$ & $16.85 \mathrm{a}$ & $29.81 \mathrm{~b}$ \\
\hline MA & 2.16 & 3.88 & 4.75 & $28.08 \mathrm{a}$ & $16.85 \mathrm{a}$ & $22.99 \mathrm{a}$ & $22.03 \mathrm{c}$ \\
\hline $\mathrm{CS}$ & 3.88 & 5.61 & 3.02 & $6.48 \mathrm{~d}$ & $17.71 \mathrm{a}$ & $19.44 \mathrm{a}$ & $21.17 \mathrm{c}$ \\
\hline $\mathrm{CO}$ & 1.29 & 5.61 & 3.88 & $21.17 \mathrm{~b}$ & $4.75 \mathrm{~b}$ & $8.20 \mathrm{~b}$ & $37.59 \mathrm{a}$ \\
\hline $\mathrm{CCB}$ & 3.88 & 4.75 & 12.53 & $28.08 \mathrm{a}$ & $11.66 \mathrm{a}$ & $15.98 \mathrm{a}$ & $11.66 \mathrm{~d}$ \\
\hline $\mathrm{CCI}$ & 6.48 & 5.61 & 6.61 & $21.17 \mathrm{~b}$ & $16.85 \mathrm{a}$ & $23.76 \mathrm{a}$ & $14.26 \mathrm{c}$ \\
\hline Control & 1.30 & 1.29 & 4.75 & $2.16 \mathrm{~d}$ & $4.75 \mathrm{~b}$ & $1.30 \mathrm{c}$ & $3.89 \mathrm{e}$ \\
\hline C.V. & 39.38 & & & & & & \\
\hline
\end{tabular}

PG - Pennisetum glaucum 'BRS 1501'; BB - Brachiaria brizantha; MA Mucuna aterrima; CO - Crotalaria ochroleuca; CS - Crotalaria spectabilis; CCB - Cajanus cajan 'IAC Broad pod'; CCI - Cajanus cajan 'IAPAR 43'; control - soil without straw; nd - no significant difference; C.V. - coefficient of variation. Means followed by the same letters in the column do not differ by Scott-Knott test $(\mathrm{p}<0.05)$

For the time period between 28 and 105 days it was observed that treatments with straw from legume plants always presented high amounts of $\mathrm{N}_{\text {mic }}$ in the soil, except in the CS treatment with an increase after 42 days when compared to the control (Table 4). The quality of straw may be related here to nitrogen stocks and cycling related to microbial nitrogen biomass, because it is an important pool of organic nitrogen with a potential for mineralization (MOREIRA; SIQUEIRA, 2006). Therefore, the higher the nitrogen content of the microbial biomass, the faster will be its cycling. This is an important tool for agricultural crop nutrition because nitrogen is often one of the most limiting nutrients and any difference in the rates of mineralization, immobilization and nitrification may have a significant effect on the sustainability of production systems (DE GENNARO et al., 2014).

In the deployment of the assessment date within each cover crop treatment, for all cover plant straw treatments studied, an increased length of incubation was observed in $\mathrm{N}_{\text {mic }}$, until the $42^{\text {nd }}$ day of incubation with stabilization of the values for nitrogen microbial biomass, except for the $\mathrm{PG}, \mathrm{CO}$ and $\mathrm{BB}$ treatment where a linear increase was observed after 63 days. Comparing the treatments with cover plant straw and control, a significant increase in the soil nitrogen stock retained in the microbial biomass was observed (Figure 3). 


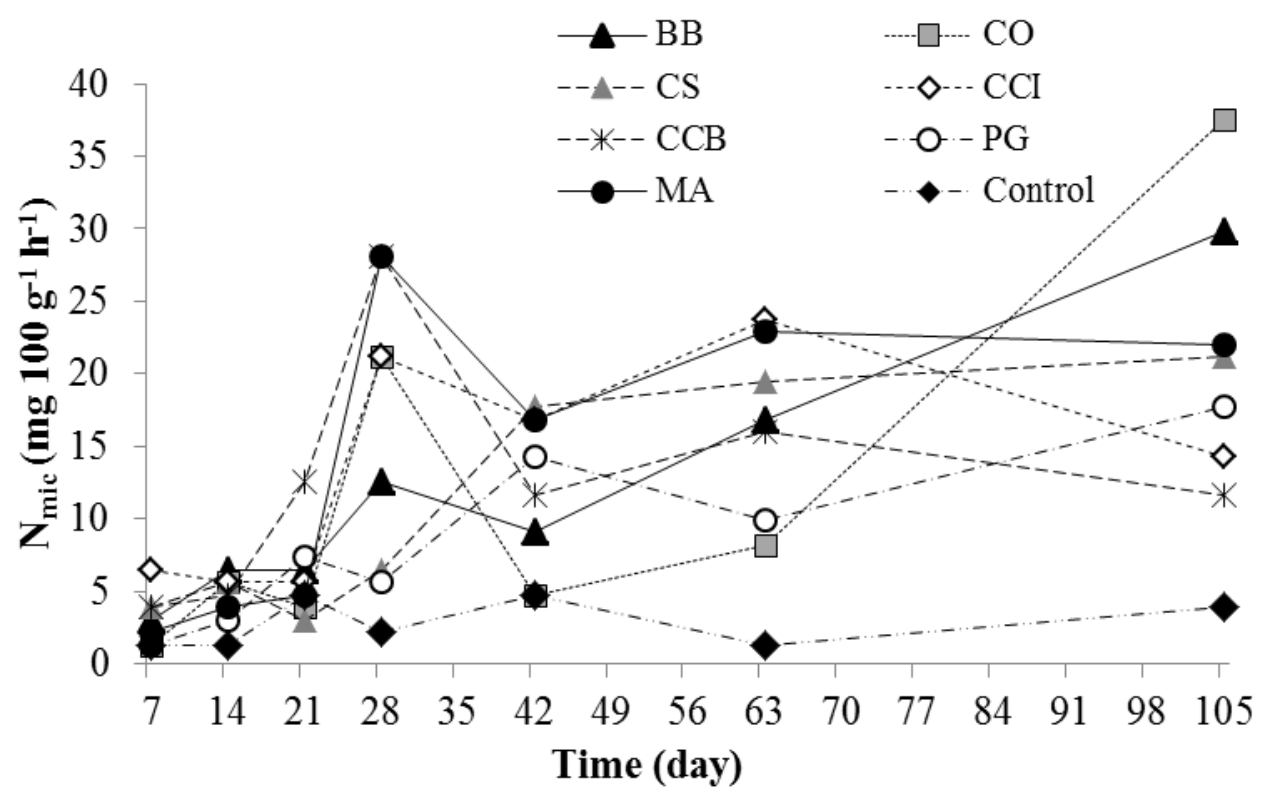

Figure 3. Microbial biomass nitrogen $\left(\mathrm{N}_{\text {mic }}\right)$ evaluation for 105 days of incubation after incorporation of grasses and legume straw in an Oxisol.

The $\mathrm{qCO}_{2}$ of the soil is a sensitive indicator of biological activity and substrate quality. In the deployment of the use of cover crops within each assessment date, the $\mathrm{qCO}_{2}$ ranged from 0.61 (CCI) to 2.89 (Control) at 7 days; $0.26(\mathrm{BB})$ to 10.81 (CS) at
14 days; $0.68(\mathrm{BB})$ to $6.19(\mathrm{CCI})$ at 21 days; 0.50 (BB) to $3.70(\mathrm{PG})$ at 28 days; $0.12(\mathrm{MA})$ to 0.66 (Control) at 42 days; 0.18 (CCI) to 0.55 (Control) at 63 days; and 0.14 (MA) to $0.35 \mathrm{mg} \mathrm{CO}_{2} \mathrm{~g}^{-1} \mathrm{C}_{\text {mic }} \mathrm{h}^{-1}$ (Control) at 105 days (Table 5).

Table 5. Metabolic quotient ( $\mathrm{mg} \mathrm{C}-\mathrm{CO}_{2} \mathrm{~g}^{-1} \mathrm{C}_{\text {mic }} \mathrm{h}^{-1}$ ) for 105 days of incubation after incorporation of grasses and legume straw in an Oxisol.

\begin{tabular}{llllllll}
\hline \multirow{2}{*}{ Treatment } & \multicolumn{7}{c}{ Period in days } \\
\cline { 2 - 8 } & 7 & 14 & 21 & 28 & 42 & 63 & 105 \\
\hline PG & $1.47 \mathrm{~b}$ & $0.80 \mathrm{~b}$ & $2.84 \mathrm{~b}$ & $3.70 \mathrm{a}$ & $0.17^{\text {nd }}$ & $0.26^{\text {nd }}$ & $0.23^{\text {nd }}$ \\
BB & $1.01 \mathrm{~b}$ & $0.26 \mathrm{~b}$ & $0.68 \mathrm{~d}$ & $0.50 \mathrm{c}$ & 0.22 & 0.25 & 0.26 \\
MA & $0.92 \mathrm{~b}$ & $0.42 \mathrm{~b}$ & $0.81 \mathrm{~d}$ & $0.59 \mathrm{c}$ & 0.12 & 0.19 & 0.14 \\
$\mathrm{CS}$ & $1.87 \mathrm{a}$ & $10.81 \mathrm{a}$ & $0.92 \mathrm{~d}$ & $0.68 \mathrm{c}$ & 0.21 & 0.23 & 0.16 \\
$\mathrm{CO}$ & $2.28 \mathrm{a}$ & $0.55 \mathrm{~b}$ & $0.70 \mathrm{~d}$ & $0.55 \mathrm{c}$ & 0.20 & 0.23 & 0.22 \\
CCB & $0.62 \mathrm{~b}$ & $0.48 \mathrm{~b}$ & $1.82 \mathrm{c}$ & $1.40 \mathrm{c}$ & 0.18 & 0.30 & 0.21 \\
CCI & $0.61 \mathrm{~b}$ & $0.61 \mathrm{~b}$ & $6.19 \mathrm{a}$ & $2.57 \mathrm{~b}$ & 0.14 & 0.18 & 0.22 \\
Control & $2.89 \mathrm{a}$ & $0.50 \mathrm{~b}$ & $0.98 \mathrm{~d}$ & $1.02 \mathrm{c}$ & 0.66 & 0.55 & 0.35 \\
\hline C.V. & 55.49 & & & & & & \\
\hline
\end{tabular}

PG - Pennisetum glaucum 'BRS 1501'; BB - Brachiaria brizantha; MA - Mucuna aterrima; CO - Crotalaria ochroleuca; CS - Crotalaria spectabilis; CCB - Cajanus cajan 'IAC Broad pod'; CCI - Cajanus cajan 'IAPAR 43'; control - soil without straw; nd - no significant difference; C.V. - coefficient of variation. Means followed by the same letters in the column do not differ by Scott-Knott test $(\mathrm{p}<0.05)$.

According to Insam and Domsch (1988), soil basal respiration per unit microbial biomass decreased in more stable systems. Based on this information it can be concluded that until 7 days of incubation $\mathrm{PG}, \mathrm{BB}, \mathrm{MA}, \mathrm{CCB}$ and $\mathrm{CCI} ; 14$ days $\mathrm{PG}$, $\mathrm{BB}, \mathrm{MA}, \mathrm{CO}, \mathrm{CCB}, \mathrm{CCI}$ and Control; 21 days BB, $\mathrm{MA}, \mathrm{CS}, \mathrm{CO}$ and control; 28 days BB, MA, CS, CO, $\mathrm{CCB}$ and control caused less stress to the microbial environment, while treatments with high $\mathrm{qCO}_{2}$ on each date of analysis show the most stressed microbial environment (Table 5).

After 42 days of incubation no significant differences were observed between treatments. Anderson and Domsch (1993) interpreted the quotient as a possible indicator of environmental stress that is directly related to the energy demand of 
maintenance of a microbial community (stress situation); this value increases to a maximum point, after which it decreases as the environment recovers over time. In this study it was observed 42 days after the incorporation of cover plant straw (Table 5).

The qMIC expresses the indexes of the nutritional quality of the organic matter by the ratio of biomass microbial $\mathrm{C}$ to total organic soil $\mathrm{C}$. In the deployment of the use of cover crops within each assessment date, the qMIC ranged from 0.1 (CS at 14 days) to $5.1 \%$ (CCI at 42 days). On the $7^{\text {th }}$ and $21^{\text {st }}$ day of incubation no significant differences were observed (Table 6).

Table 6. Microbial quotient (\%) for 105 days of incubation after incorporation of grasses and legume straw in an Oxisol.

\begin{tabular}{llllllll}
\hline \multirow{2}{*}{ Treatment } & \multicolumn{7}{l}{ Period in days } \\
\cline { 2 - 8 } & 7 & 14 & 21 & 28 & 42 & 63 & 105 \\
\hline PG & $0.4^{\text {nd }}$ & $3.7 \mathrm{a}$ & $0.3^{\text {nd }}$ & $0.1 \mathrm{~b}$ & $2.2 \mathrm{~b}$ & $4.3 \mathrm{a}$ & $2.5 \mathrm{a}$ \\
BB & 0.7 & $4.2 \mathrm{a}$ & 1.5 & $1.7 \mathrm{a}$ & $2.9 \mathrm{~b}$ & $3.5 \mathrm{a}$ & $1.7 \mathrm{~b}$ \\
MA & 0.7 & $2.6 \mathrm{~b}$ & 1.1 & $1.6 \mathrm{a}$ & $4.1 \mathrm{a}$ & $3.6 \mathrm{a}$ & $2.5 \mathrm{a}$ \\
$\mathrm{CS}$ & 0.4 & $0.1 \mathrm{c}$ & 1.3 & $1.3 \mathrm{a}$ & $3.9 \mathrm{a}$ & $3.9 \mathrm{a}$ & $3.0 \mathrm{a}$ \\
$\mathrm{CO}$ & 0.5 & $2.1 \mathrm{~b}$ & 1.8 & $1.6 \mathrm{a}$ & $4.0 \mathrm{a}$ & $4.0 \mathrm{a}$ & $2.1 \mathrm{a}$ \\
CCB & 1.0 & $3.0 \mathrm{~b}$ & 1.2 & $0.5 \mathrm{~b}$ & $4.3 \mathrm{a}$ & $3.8 \mathrm{a}$ & $1.9 \mathrm{a}$ \\
CCI & 1.6 & $2.7 \mathrm{~b}$ & 0.2 & $0.5 \mathrm{~b}$ & $5.1 \mathrm{a}$ & $3.9 \mathrm{a}$ & $1.4 \mathrm{~b}$ \\
Control & 0.2 & $0.5 \mathrm{c}$ & 0.3 & $0.4 \mathrm{~b}$ & $0.7 \mathrm{c}$ & $0.4 \mathrm{~b}$ & $0.4 \mathrm{~b}$ \\
\hline C.V. & 41.16 & & & & & & \\
\hline
\end{tabular}

PG - Pennisetum glaucum 'BRS 1501'; BB - Brachiaria brizantha; MA - Mucuna aterrima; CO - Crotalaria ochroleuca; CS - Crotalaria spectabilis; CCB - Cajanus cajan 'IAC Broad pod'; CCI - Cajanus cajan 'IAPAR 43'; control - soil without straw; nd - no significant difference; C.V. - coefficient of variation. Means followed by the same letters in the column do not differ by Scott-Knott test $(\mathrm{p}<0.05)$.

At 14 days of incubation the highest values ( 3.7 and $4.2 \%$ ) for qMIC were found in the treatment $\mathrm{PG}$ and BB, respectively, and lower values $(0.1$ and $0.5 \%$ ) were observed in CS and control, respectively. This probably occurs because the control (treatment without straw) has a low SOM concentration and this organic material may be in an advanced stage of degradation as fluvic and humic acids or humina, preventing the native microbiota from using these recalcitrant carbon sources (MOREIRA; SIQUEIRA, 2006). At the time of the CS straw harvest, a great amount of organic material formed only by plant stems was observed as explained previously.

Treatments BB, MA, CS and CO have high amounts of qMIC at 28 days of incubation, followed by other treatments. However, values were not considered very high. Martins et al. (2010) studying chemical and microbial attributes of dry and rainy periods, observed values for qMIC in a conserved environment ranging from 1.6 (rainy) to $2.6 \%$ (dry); in a moderately degraded environment ranging from 1.0 (dry) to $1.6 \%$ (rainy) and in an intensely degraded environment ranging from 0.8 (rainy) to $1.2 \%$ (dry).

At 42 days treatments with legume straw presented higher values ranging from 3.9 (CS to $5.1 \%$ (CCI), followed by control and treatments with grass straw. All treatments increased the qMIC during the incubation period until between the $42^{\text {nd }}$ and $63^{\text {rd }}$ days, except for the control. After the 63 days of incubation a small drop in the qMIC values was observed in the treatments with cover plant straw. However, at 105 days the treatments PG, MA, $\mathrm{CS}, \mathrm{CO}$ and $\mathrm{CCB}$ have high amounts of qMIC $(>1.4$ $>3.0 \%$ ) as shown in Table 6 . These values indicate that the soil carbon is available to micro-organisms. High indexes of qMic indicate that the soil organic matter is active and is subject to decomposition by microbiota. Furthermore, organic matter is the best environmental predictor to determine the activity of microbial communities, because of the increased proportion of genes associated with energy metabolism, carbohydrate metabolism and xenobiotics biodegradation and metabolism, indicating higher levels of soil nutrient cycling (GUO et al., 2018).

All the evaluated species presented a potential to be used in crop rotation systems, making notillage system feasible in the Cerrado region of Piauí. However, it is recommended to select species according to specific purposes (soil quality, nutrient cycling, soil surface cover, or dry mass production).

Knowing the temporal dynamics of $\mathrm{N}$ mineralization or immobilization of the different cover crops it is important to manage the agricultural systems in the Cerrado. It is also necessary to choose the correct species to be used and the ideal moment to sow the following crop so that the decomposition and release of nutrients by the cover plants can happen in the period of greater demand by the following crop (SOUSA et al., 2019). 
Thus, this work found that the use of cover crops is an important tool for improving the biological quality of the Cerrado soils of the Northeast region, which is a new and expanding agricultural frontier in Brazil.

\section{CONCLUSIONS}

The microbial population of the soil and their activity measured by soil basal respiration are affected by the cover crop species, both with legumes and grass straw. Until 21 days no differences are observed between treatments for $\mathrm{N}_{\text {mic }}$. After 21 days of incubation, all treatments with mixed straw presented the same or higher $\mathrm{N}_{\text {mic }}$ content than the control on the evaluated dates.

The incorporation of Brachiaria brizantha and Mucuna aterrima had a positive impact on the microbial properties of the analyzed soil until the $21^{\text {st }}$ incubation (metabolic quotient, microbial biomass carbon and nitrogen), with little loss of carbon dioxide followed by a growth of the microbial population.

At 105 days, the highest indexes of nutritional quality of organic matter are obtained with straw of Pennisetum glaucum, Crotalaria ochroleuca, Crotalaria spectabilis, Cajanus cajan 'IAC Broad pod' and Mucuna aterrima.

The use of cover plant straw in the soil in a Cerrado environment stimulates soil microbial activity over 105 days, compared to the absence of straw in the biological system, thus allowing unrestricted access to the genetic package and diversity of functions of these populations.

\section{ACKNOWLEDGEMENTS}

The authors thank Coordination for the Improvement of Higher Education Personnel (CAPES) for a Master's degree scholarship for the first author, National Council for Scientific and Technological (CNPq) for PQ Fellowships (Processes number: 303952/2017-2) and the Piraí Sementes company for kindly donating the seeds.

\section{REFERENCES}

ANDERSON, J. P. E.; DOMSH, K. H. The metabolic quotient $\left(\mathrm{qCO}_{2}\right)$ as a specific activity parameter to assess the effects of the environment conditions, such as $\mathrm{pH}$, microbial biomass on the soils of forest. Soil Biology and Biochemistry, 25: 393-395, 1993.

BOECHAT, C. L. et al. Industrial and urban organic wastes increase soil microbial activity and biomass.
Revista Brasileira de Ciência do Solo, 36: 16291636, 2012.

BOECHAT, C. L. et al. Net mineralization nitrogen and soil chemical changes with application of organic wastes with 'Fermented Bokashi Compost'. Acta Scientiarum. Agronomy, 35: 257-264, 2013.

BROOKES, P. C. et al. Chloroform fumigation and release of soil N: A rapid direct extraction method to measure microbial biomass $\mathrm{N}$ in soil. Soil Biology and Biochemistry, 17: 837-842, 1985.

BURNS, R. G. et al. Soil enzymes in a changing environment: Current knowledge and future directions. Soil Biology and Biochemistry, 58: 216234,2013

CARDOSO, E. J. B. N.; ANDREOTE, F. D. Microbiologia do solo. 3. ed. Piracicaba, SP: ESALQ, 2016. 221 p.

DE GENNARO, L. A. et al. Soil physical and microbiological attributes cultivated with the common bean under two management systems. Revista Ciência Agronômica, 45: 641-649, 2014.

FERREIRA, A. S.; CAMARGO, F. A. O.; VIDOR, C. Utilização de microondas na avaliação da biomassa microbiana do solo. Revista Brasileira de Ciência do Solo, 23: 991-996, 1999.

FERREIRA, D. F. Sisvar: a computer statistical analysis system. Ciência e Agrotecnologia, 35: 1039-1042, 2011.

FERREIRA, E. P. B.; WENDLAND, A.; DIDONET, A. D. Microbial biomass and enzyme activity of a Cerrado Oxisol under agroecological production system. Bragantia, 70: 899-907, 2011.

FONTANA, A. et al. Característica e atributos de Latossolos sob diferentes usos em Luis Eduardo Magalhaes, Bahia. Pesquisa Agropecuária Brasileira, 51: 1457-1465, 2016.

GUO, Y. et al. Natural revegetation of a semiarid habitat alters taxonomic and functional diversity of soil microbial communities. Science of The Total Environment, 635: 598-606, 2018.

$\mathrm{HU}$, Y. et al. Influence of ecological restoration on vegetation and soil microbiological properties in Alpine-cold semi-humid decertified land. Ecological Engineering, 94: 88-94, 2016.

INSAM, H.; DOMSCH, K. H. Relationship between soil organic carbon and microbial biomass on chronosequences of reclamation sites. Microbial Ecology, 47: 177-188, 1988. 
ISLAM, K. R.; WEIL, R. R. Microwave irradiation of soil for routine measurement of microbial biomass carbon. Biology and Fertility of Soils, 27: 408-416, 1998.

JENKINSON, D. S.; POWLSON, D. S. The effects of biocidal treatments on metabolism in soil-I. Fumigation with chloroform. Soil Biology and Biochemistry, 8: 167-177, 1976.

MANDAKOVIC, D. et al. Structure and cooccurrence patterns in microbial communities under acute environmental stress reveal ecological factors fostering resilience. Scientific Reports, 8: e5875, 2018.

MARTINS, C. M. et al. Atributos químicos e microbianos do solo de áreas em processo de desertificação no semiárido de Pernambuco. Revista Brasileira de Ciência do Solo, 34: 1883-1890, 2010.

MOREIRA, F. M. S.; SIQUEIRA, J. O. Microbiologia e bioquímica do solo. 2. ed. Lavras, MG: UFLA, 2006. 729 p.

NOVAK, E. et al. Chemical and microbiological attributes under different soil cover. Cerne, 23: 1930, 2017.

OLIVEIRA, W. R. D. et al. Dynamics of soil microbiological attributes under integrated production systems, continuous pasture, and native cerrado. Pesquisa Agropecuária Brasileira, 51: 1501-1510, 2016.

RODRÍGUEZ, J. et al. Physico-chemical and microbial perturbations of Andalusian pine forest soils following a wildfire. Science of the Total Environment, 634: 650-660, 2018.

SANTOS, H. G. et al. Sistema brasileiro de classificação de solo. 3. ed. Brasília, DF: Embrapa, 2013. $221 \mathrm{p}$.

SANTOS, J. V. et al. Biological attributes of rehabilitated soils contaminated with heavy metals. Environmental Science and Pollution Research, 23: 6735-6748, 2016.

SOIL SURVEY STAFF. Keys to Soil Taxonomy. 12. ed. Washington: USDA - Natural Resources Conservation Service, 2014. 362 p.

SOUSA, D. C. et al. Dry mass accumulation, nutrients and decomposition of cover plants. Journal of Agricultural Science, 11: 152-160, 2019.
M. G. Soil organic matter as affected by management systems, phosphate fertilization, and cover crops. Pesquisa Agropecuária Brasileira, 51: 1668-1676, 2016.

SZOBOSZLAY, M.; WHITE-MONSANT, A.; MOE, L. A. The Effect of Root Exudate 7,4'Dihydroxyflavone and Naringenin on Soil Bacterial Community Structure. Plos one, 11: e0146555, 2016.

TEDESCO, M. J. et al. Análises de solo, plantas e outros materiais. Porto Alegre, RS: UFGRS, 1995. $174 \mathrm{p}$.

WALKLEY, A.; BLACK, I. A. An examination of the Degtjarref method for determining soil organic matter, and a proposed modification of the chromic acid titration method. Soil Science, 37: 29-38, 1934.

ZHANG, J. et al. Effects of straw incorporation on soil nutrients, enzymes, and aggregate stability in tobacco fields of China. Sustainability, 8: 1-12, 2016.

ZHANG, Q. et al. Effects of different organic manures on the biochemical and microbial characteristics of albic paddy soil in a short-term experiment. Plos one, 10: e0124096, 2015a.

ZHANG, Y. L. et al. Response of soil enzyme activity to long-term restoration of desertified land. Catena, 133: 64-70, 2015b.

SOUZA, G. P.; FIGUEIREDO, C. C.; SOUSA, D. 